\author{
Milica JAKÓBIEC-SEMKOWOWA* \\ Uniwersytet Wrocławski \\ Instytut Filologii Słowiańskiej
}

Оригинални научни рад

Примљен: 11. 11. 2016. Прихваћен: 10. 02. 2017.

\title{
ПРИПОВЕДАЧКИ ПОКУШАЈИ БРАНКА РАДИЧЕВИЋА
}

\begin{abstract}
Епске песме Бранка Радичевића су по обиму већи део његовог песничког опуса, али у многим студијама и монографијама остају у сенци његове лирике. Циљ овог излагања је доказати до које мере је аутор „Ђачког растанка” савладао вештину епског приповедања, да ли се у грађењу приче ослањао на епску традицију претходних епоха - класицизма и предромантизма - или су му биле ближе романтичарске поеме бајроновског типа.
\end{abstract}

Кључне речи: романтичарска поема, приповедање, композиција, стих, лирика.

Од преране смрти Бранка Радичевића прошло је више од 160 година, пуних бурних историјских догађаја и великих цивилизацијских промена, које су утицале на његову рецепцију. Данас читамо Бранкова дела као сведочанство епохе у којој је живео и коју је својим опусом променио. Не сумњамо да је његово место чврсто утемељено у историји књижевности, грађено на заслугама за српску лирику, иако су се већ две деценије после његове смрти појавили критички судови Лазе Костића, а почетком 20. века Јована Скерлића (в. Вуковић 1978: 195-196, Јовићевић 2012). Када је поводом стоте годишњице песниковог рођења Павле Поповић припремио за Српску књижевну задругу књигу његових песама допуњену писмима, списом у прози и обимним уводом (Поповић 1924), главно је питање било до које мере је Бранкова поезија жива и читљива у двадесетим годинама 20. века. Скоро сто година касније Бранко је у српској култури стално присутан: и у школским читанкама, и у програмима екскурзија на Стражилово и у именима многих културних установа. То не значи да се већ све о њему зна и да је његово стваралаштво подробно описано. Нови изазов може бити истраживање читавог песниковог опуса (штампаног и нештампаног), што је могуће захваљујући доступности текстова на Интернетуํㅗㄹ И ту следи прво изненађење: рачунајући по броју стихо-

\footnotetext{
*milicasemkova@gmail.com

${ }^{1}$ Сви цитати Радичевићевих дела преузети су са www.antologijasrpskeknjizevnosti.rs. У тексту су дати наслови и бројеви стихова (нпр. Гојко 21).
} 
ва, у Бранковој заоставштини има много више стихова који припадају епици. Током живота Бранко Радичевић је штампао пет поема. То су: „,”² („Никад није вито...”), „Ђачки растанак” и „Пут” у првој књизи песама (1847) и „Гојко” и „Хајдуков гроб” у другој књизи (1851). У рукопису су остале следеће: „Туга и опомена”, „Безимена”, „Стојан”, „Утопљеница”, „Освета”, „Урош” и (недовршене) „Милета” и „Одломак”. У електронској едицији Бранкова дела заузимају укупно преко 700 страница од чега близу 400 припада епици (тј. 11.563 стихова), која у многим студијама и монографијама остаје у дубокој сенци његове лирике; велики део Радичевићевог опуса није био истраживан. Анализиране су појединачне поеме као „Туга и опомена” (Поповић 1919), „Пут” (Дамјанов 1997) и темељно обрађена „Безимена” (Поповић 1969). О осталим поемама, чак и у исцрпном раду Павла Поповића, чешће налазимо оцене него анализе. Пише нпр. Поповић да је „Хајдуков гроб” „много бољи него Гојко” (1924: CXXIX), „Стојан је мање клише него Гојко” (Поповић 1924: CXXXII), „најбоља од свих је Утопљеница заједно са Осветом” (1924: CXXXVII), и „не бих имао много лепог да кажем о Безименој песми” (1924: CXXXVII). Предубеђење аутора увода види се по избору текстова; загледан у лирику, Поповић је у својој едицији у Српској књижевној задрузи изоставио поему „Милета” иако је доста места посветио доказивању да је ова поема безвредна, што није до краја тачно.

Радичевићеву епику у последње време помиње Татјана Јовићевић у антологијској серији Десет векова српске књижевности, закључујући да епске песме из друге штампане Бранкове књиге, као и сатирично-бурлескне поеме из заоставштине, ,jош увек траже место и смисао унутар песниковог опуса" и „можда показују могуће правце његовог певања” (Јовићевић 2012: 20).

Пошто је циљ нашег рада разматрање питања везаних за наратологију, нећемо се бавити општим карактеристикама читавог Бранковог епског певања. Међутим, вреди обратити пажњу на неколико примедби које могу разјаснити песникове покушаје у грађењу нове српске епике. Нема сумње да је песник мислио на то; већ 1844. је „намислио један мали епос писати” и послао тада оцу „предпев” (Поповић 1924: CXIX-CXX), а у августу 1847. најављује да ће „на зиму, ако Бог да, епос издати” (Живковић 1995: 230). Шта је за њега значио „епос”?

Класицистички образован, начитан углавном на немачком, који му је био први језик књижевне културе, могао се Бранко Радичевић обратити европској, античкој традицији епског певања коју је француски класицизам освежио и формулисао строге принципе нормативне поетике, такође у односу на приповедање. Класицистичка начела нису била страна српским просветитељима. Међутим, почетак 19. века је време процвата романтичарске поеме, која је настала као отпор према класицизму и која је, поред новог хероја, донела потпуно нова решења у организацији текста. Епско излагање je у поемама бајроновског типа прекидано размишљањима и ерупцијама личних песникових емоција, а и многи догађаји развијене, замршене фабуле

\footnotetext{
${ }^{2}$ У наслову је само знак питања, даље ће бити у употреби инципит „Никад није”.
} 
прожети су лириком. Међутим, када је Бранко дошао у Беч, почетком четрдесетих година 19. века, европски романтизам је већ био у опадању: велики Енглези Бајрон и Шели већ су давно преминули, велики Словени Пушкин, Љермонтов и Мицкјевич или већ нису били међу живима или су заћутали. Хајне је обогатио немачки романтизам, раније окренут према средњем веку и фантастици, новим приступом према стварности: иронијом и сарказмом. У Француској поред „детета века", Мисета, и Виктора Игоа, најактивнији је Балзак, велики зачетник реализма (који је умро још пре Бранка - 1850. године). Свакако се може сматрати да је модел романтичарске бајроновске поеме могао бити други примамљив предлог за младог песника, о чему је још скоро пре сто година писао Тихомир Остојић (Остојић 1918).

Радичевићу су ипак били најближи Вук Караџић и народна песма. Велики и добро описан утицај реформатора српске културе на Бранка (в. Белић 1947; Клеут 1973) не своди се само на избор језика и метрике, на избор начина изражавања који је сличан народној лирици. То је, такође, утицај велике епике, ризнице тема и мотива, форме, начина приповедања. На овој подлози могла би се извести реформа српске уметничке епске поезије.

Током свог кратког живота, непуних 10 година песничке активности, Бранко је - свестан свог талента и могућности - тражио место у књижевности. У Бечу, једном од главних центара европске културе тог доба, широко отворених очију и ушију, жедан успеха (ваљда не у студијама права!), лутајући по књижарама пуним новости, Бранко Радичевић тражи себе - песника. Приповедачки покушаји су сведочанство ових трагања јер као песник-лиричар остаје скоро исти, само му болест додаје нове теме и нову боју.

Прво питање везано за конструкцију Радичевићевих поема тиче се метрике: да ли је избор теме утицао на метрички облик текста, да ли су поеме, грађене на мотивима хајдучке народне песме, писане десетерачким стихом? То се тиче „Гојка”, „Хајдуковог гроба” и нештампаног „Милете”, „Уроша и Стојана”. Десетерац је песник искористио само у штампаним поемама. „Урош” је написан осмерцем, што би се могло повезивати са традицијом баладе, у „Стојану” имамо јамбски једанаестерац. Епски десетерац је такође послужио песнику у осталим штампаним поемама: у „Ђачком растанку” (где поред њега имамо читаво богатство других стихова!), „Никад није...” и у „Путу”. И то би могао бити први закључак: Радичевић је посматрао епски десетерац као природно, „безбедно” метричко средство, а у необјављеним поемама песник ће се мерити са другим версификационим размерима, најуспешније у „Стојану”.

Друго питање које би могло разјаснити Бранков став према епској традицији тиче се приповедача и приповедања. Бранкова несумњива наклоност према лирици испољавала се у већини епских текстова; од емоционалних увода до доминације чисто лирског сензибилитета: међутим, у лирским поемама владају друга правила: логика емоција, доживљавања света, а не редослед догађаја. Приповедање у, грађеном на личном узбуђењу, „Ђачком растанку” (,чедно-детиње доживљавање света” сагласно са народним духом, Живковић 1995: 127) и у, пуној тужних дубоких размишљања, „Тузи и опо- 
мени" не може се упоређивати са епским причама развијеним у другим текстовима. А скоро све остале поеме почињу од лирског увода.

Почетак „Никад није...” је регуларни сонет „Никад није вито твоје тело / рука моја млада обавила" (Никад није... 1-2), потом следи приповедање у првом лицу, насићено емоционалним перципирањем природе. У „Гојку” почетни ауторски стихови (26) представљају апострофу упућену гуслама и певању која води ка рефлексији о пролазности живота и трајању песме. Речима: „Ал’ што певах неће пропанути, / Након мене хоће останути” (Гојко: 21-22), млади Бранко се укључује у романтичарски хор песника уверених у моћ поезије, што ће најкраће формулисати Мицкјевич речима „песма ће преживети”. У нештампаној поеми „Безимена” духовит, помало шаљив лирски увод подражава народну песму: „А мој брате драги, мили, / Ал’ ме тиште ране, / Раниле ме девојчице / Гиздаве, млађане.” (Безимена I: 1-4) Трећи део ове поеме почиње класичком, античком апострофом „Горе, песмо лакокрила", али одмах се тај узвишени тон мења:

„Ал' не вод’ ме на небеса,

Ниже пусти своја крила,

Нису за ме та чудеса,

Пут је тамо студен, ладан,

Мога̂ би се смрзнут јадан" (Безимена III: 1-6).

Скоро у сваком тексту видљиви приповедач/аутор је потпуно субјективан; лиризација укључује Бранкове поеме у широк круг европског романтизма.

Прилагођавање бајроновским узорима у приповедању може се доказати у упоређењу „Милете” и „Гојка”. Павле Поповић у поменутом уводу у Песме Бранка Радичевића третира „Милету” као прву редакцију истог мотива, („Гојко постао из тзв. Милете, тј. из једне врло рђаве песме”, Поповић 1924: 127) „слабу, сасвим слабу ствар, и пуну, препуну наивности, 'безредија', лудости” (Поповић 1924: 123), а рад на „Гојку” као исправљање грешака. Поповић пише да је „песник сам одбацио Милету и закопао га једном за свагда; према томе тај спев не треба више дирати” (Поповић 1924: CXXIII-CXXIV). „Закопавање” ипак није аргумент; међу нештампаним, „закопаним”, поемама нашла се нпр. високооцењена „Туга и опомена”. Међутим иако је први део „Милете” написан 1844. у пролеће, други и трећи су настали тек у априлу 1848 , паралелно са „Гојком”, насталим у пролеће исте године, што значи да су поеме писане у исто време. За штампу је Бранко изабрао „Гојка”.

Прва разлика која сведочи о постојању два засебна текста су имена главних јунака, која се налазе у насловима. Друкчије се такође зову очеви хероја: Милетин отац је Змај Огњени Раде, а Гојков - Змај Милутин, што је у току радње веома значајно. Већ на први поглед се види такође да је други текст, у целини настао касније - краћи; већ само прва песма „Милете” има 868 стихова а „Гојка” - само 539 (у целини разлике су још веће: 2.977 и 1.069), а баш у томе шта је песник избацио види се правац и циљ измена. Радња почиње од описа олује; Милета без страха посматра олују из свог „белог двора”, ближу карактеристику јунака допуњује упоређење са муњом.Тек ујутро после олује 
спрема се ићи у лов. У „Гојку” кратак опис олује није повезан са јунаком, већ гради атмосферу. Карактеризација главног хероја своди се само на речи: „соко је ка̂ му отац био” (Гојко: 41). У „Милети” следи оправдање за лов:

„Кад не иду чете на Турчина,

А он тражи зверке по планина,

Кад не сече Ибре и Мемеде,

А он бије вуке и медведе;” (Милета: 86-89),

даље иде сређивање ловачке опреме, безуспешна јурњава по шуми и планини и најзад друга олуја која задржава јунака на непознатом месту. Сви ови ситни догађаји су логично повезани, само понекад спољашни проповедач умеће своје екскламације: „Ох мој Боже, сад је сасвим тавно” (Милета: 131), „Боже силни, [...] Ал’ помози Милети јаднику!” (Милета: 144-145). Безуспешан лов и друга олуја су у „Гојку” приказани скраћено, а јунаково узбуђење поводом лутања приказано је помоћу низа питања које поставља наратор, типа: „Да л’ још лута, да л’ санак борави?” (Гојко: 69). Низ приповедачких питања појачава драматургију текста. Други дан безуспешног лова претходи у „Милети” наредном догађају, сну о медведу, који је исти у оба текста. После ноћне море приповедач у „Милети” прво детаљно описује буђење јунака, трагање за водом, умивање, одмарање после лова. Радња тече полако, без икакве драматургије. Све је то у „Гојку” изостављено, а коначни ефекат је сажетост и драматизација приче.

Други пример пропуштања ситних елемената радње може се видети у сцени вечере код Рајка Жеравице, оца лепе Цвете (ови ликови су исти у оба текста), који у „Милети” наређује да се припрема богата вечера; помињу се разна јела и напици, тек после почиње разговор, питање о имену и у складу са епским повезивањем елемената приче: „Тако пита Рајко, сабља стара, А Милета њему одговора" (Милета: 394-395). Ни вечере ни уводне конверзације у „Гојку” нема, као ни припреме изненађења, открића из прошлости, јер Милетино лице подсећа Жеравицу на неког познаника из младости. Нема такође описа Жеравичиног узбуђења, суза („Старини је и мило и тешко”, Милета: 407), загрљаја: „Па га љуби у чело витешко, Јоште проли две големе сузе”, (Милета: 408-409). Много је шира, такође у „Милети”, прича о заједничком животу два побратима, не само о војевању. У „Гојку” се откриће давних веза очева своди на: „та Бога ти, сине! / Кликну старац, мило му бејаше, / Па овако даље бесеђаше" (Гојко: 168-170). Још један пример који потврђује потпуно другачију концепцију организације приче може се наћи при крају првог дела „Милете” и „Гојка” када се срећан јунак са побратимом Радојем враћа кући после прошења лепе Цвете. Милета/Гојко види да је његов побратим тужан, а одговарајући на питање, каже да је то због сећања на умрлу сестру. У „Милети” се пак појављује ауторска сумња, као зачетак нове приче: „Беше л’ сетан баш зато заисто? Је л’ му срце као лице чисто?” (Милета: 851-852).

„Милета” и „Гојко” су две варијанте истог, доста замршеног љубавно-јуначког сижеа са развијеном евокацијом прошлости; промена имена јунака 
је безначајна јер су ликови и карактери остали исти. ${ }^{3}$ Преобликован је ипак модел приповедања: од типично епског до романтичке поеме, чији је приповедач егзалтиран. Поред типично лирских допуна и драматизације текста (чешће су укључавани дијалози, приповедачка питања, емоционални коментари) радња се креће слободно, „скаче” са једног догађаја на други. Из логично сређених сцена и описа у „Милети” приповедач бира само оне који су неопходни (Жирмунски 1924: 44). За романтичарску поему није потребно да се објасни како и с ким је дошао Гојко у „беле дворе” Жеравића и како је изгледала вечера. Међутим - и то је доказ традиционалне организације приче - наредни догађаји су у „Гојку” ређани по темпоралном принципу, нове епизоде почињу од речи: „ноћца оде, сину зора бела” (Гојко: 358$)$, „Већ је подне” (Гојко: 389), „сунце зађе - ноћ је” (Гојко: 450).

Један од начина манифестације песничке слободе је било изостављање приче без завршетка и Радичевић је често користио ово средство. У већини поема аутор, поистовећен са приповедачем, наглашава крај песме што не значи да је радња приведена крају. У „Путу” радња се нагло прекине речима: „Уједанпут страшно чудо ново - / Ал’ за сада доста је и ово” (Пут: 1040). У претпоследњој строфи прве песме Безимене приповедач каже: „Што би даље, није ствари, / Зато песма о свем ћути” (Безимена I: 600-601), а у трећој песми прекида драматичну сцену речима: „Збогом, збогом, ја вас славим, / Али нећу да заглавим!” (Безимена III: 850-851). Зар неочекиван прекид радње у драматичном тренутку не подсећа на Сентиментално путовање Лоренца Стерна - један од путоказа новог типа приповедања? Лирски карактер има завршетак „Никад није....” Радња није приведена крају, лирски приповедач, јунак није нашао девојку и зато каже:

„Ето, браћо, песме без свршетка,

Ето, браћо, два-три уздисаја,

Ето, браћо, до два, до три цветка,

Тедо вама да оплетем венца" (Никад није...: 326-329),

али у последњој строфи нада се да ће некад успети да „допевам појак овај свети, / Браћо мила за живота свога" (Никад није...: 339-340).

Без приповедачког коментара остаје лирски крај „Туге и опомене”, сличну карактеристику имају последњи стихови „Ђачког растанка”. Није до краја јасна ситуација јунака, главног хероја „Уроша”, у „Утопљеници” јунак просто нестаје. На крају прве песме „Милете”, приповедач наглашава:

Ох, песмица нека ми је проста,

Ал’ засада свакако је доста. (Милета I: 867-868),

а на крају треће песме оставља јунака Милету у драматичној ситуацији и обраћа се директно слушаоцу/читаоцу: „Али ево шта је после било — / Но се мени грло осушило... / Дајде, брате, лозовине мало, / А тако те драго не

\footnotetext{
${ }^{3}$ Према П. Поповићу главни јунаци су ближи западноевропском „ритерском свету” него херојима српске народне епике (Поповић 1924: CXXV).
} 
варало!” (Милета III: 2381-2384). Са недовршеном радњом, без завршних објашњења, сусрећемо се такође у „Одломку” (може се претпоставити да песник није стигао да доврши љубавну сцену, додуше пуну еротике) и у другој песми „Милете” где је прекинут опис битке. ${ }^{4}$

Ради допуне прегледа начина завршавања приче треба приметити да је само у пет текстова акција приведена крају. Коначно решење доноси последња песма „Милете” и „Гојка”; скоро истим речима радња прибегава срећном финалу („Роди Цвета синке једнолике...” Гојко: 1059, Милета: 2968). Једини пут тај елеменат песме, завршетак, у „Гојку” је развијенији него у „Милети”: песник се прво обраћа слушаоцу да са разумевањем прими песму и „опрости [...] што [...] није боља” (Гојко: 1066). Ипак у оба случаја песник на крају користи формулу народне песме. У „Милети”: „Само вама нек је, браћо, слатко, / А је л' вама, онда је и мени — / А да сте ми здрави и поштени!” (Милета: 2975-2977), а у „Гојку”: „Свакојако жив и здрав ми био, // И кад има, рујно винце пио!” (Гојко: 1068-1069). Завршена радња је у „Освети”, у „Стојану”, где лирски приповедач додаје поруку: „Сад иди у свет, моја јадна песмо” (Стојан: 826) и „Хајдуковом гробу”, где је епски завршетак развијено запажање: „Већ је давно када ово бјеше” (Хајдуков гроб: 472).

Сви овде наведени примери разних облика завршетака поема сведоче о романтичарској природи песника који оставља низ нејасноћа, радњу без коначног решења, али - као прави лиричар - додаје свој лирски коментар. Из епске традиције јуначких песама остају само одјеци хајдучких тема и понекад типичне формуле („То говори а с душом се бори”, Гојко: 710), изразе, епитете и друга стилска средства што би могло бити тема засебних истраживања.

Међу епским спевовима везаним за народну традицију наилазимо на два потпуно другачија текста. То је „Пут”, штампан у првој Бранковој збирци и нештампана дужа поема „Безимена” о којој је Миодраг Поповић писао као о „првом реалистичком роману у српској књижевности” (Поповић 1969: 819), а Драгиша Живковић да је то „малтене роман” (Живковић 1995: 230). „Пут” је опширно анализирао Павле Поповић објашњавајући многе алегорије, пре свега везане за српски књижевни живот, борбу за Вукове реформе и сл. (Поповић 1924: LXXVII-LXXXVI). Према П. Поповићу „Пут” је „песничка алегорична сатира" - сасвим нов ,род” у српској поезији. Живковић подробније формулише суд о „Путу” говорећи о „сатиричкој инвентивности, израженој врло успелом хиперболом и карикатуром” (Живковић 1995: 230). Живковић помиње такође „бајроновско-пушкинско-хајнеовски [...] однос према свему инертном, баналном и тривијалном у животу” (Живковић 1995: 230). Велика имена европских песника, који су свој однос према свету исказивали у романтичним поемама, међу које је Живковић уврстио и Бранково дело дозвољавајући да се и његов „Пут” смести у оквире типично романтичарских поема те да се у овом контексту испитују приповедачка средства којима се

\footnotetext{
${ }^{4}$ П. Поповић тврди да је Бранко „имао мало способности за стварање правог јуначког епа. Он није Његош; није ни Црногорац, ратник; он не зна шта је бој, рат, јуначка мука. Код Бранка то је само занос, нешто књишко, 'литература"” (Поповић 1924: CXXIII).
} 
песник служио. Кратка и тачна Поповићева карактеристика форме: „приповетка [...] добро је вођена", али не представља целину, само низ слика повезаних мотивом пута (на Пегазу), може се допунити примедбом да се на крају радња/путовање нагло прекида. Приповедање тече брзо, у опису нпр. бежања пред опасним непријатељима наоружаним „каменом са Олимпа”, „пламеном Еликона" и страшним јегожетом, песник се служи кратким реченицама пуним динамике. Експресију појачавају емоционални узвици као нпр.: „Шта ћу сада, Боже, и како ћу?” (Пут: 233), „Ао мили што ћу ли ти Боже” (Пут: 366). Дигресије којима песник прекида радњу (прича о Црној Гори сцена коју песник гледа на ливади) потенцирају утисак слободе - највеће вредности за романтичара. А шири контекст овог типа приповедања чини хајнеовска поема „Немачка - једна зимска прича” и „Сан” Тараса Шевченке, оба дела штампана 1844. године.

„Безимену” је опширно анализирао Миодраг Павловић указујући пре свега на утицај Евгенија Оюегина, интересантна запажања је такође представио Живковић у уводу за Изабрана дела. Развијена је теза о „сатиричкој инвентивности”, поменута „прецизност у опсервацији и ноншалантност у тону" (Живковић 1995: 230). После лирског увода радња почиње од описа места (град Беч - иако није именован) и времена (тачно пет сати после подне). Тек после приказани су хероји: девојка Лиза и млади Србин. Следи прича у коју се приповедач понекад укључује са кратким напоменама везаним за јунаке, наглашава да није свезнајући („Он би код ње позадуго, / Али не знам што збораше”, Безимена: 173-174). На причу о љубавној авантури, описаној са раскалашним детаљима, надовезује се озбиљнија рефлексија о опасности којој је изложен млади Србин у велеграду, о утицају туђинске цивилизације, а у ствари - псеудокултуре. „Безимена” се састоји од три песме са уводом: прва са недовршеном радњом али са коментаром, друга - кратка, не до краја јасна и трећа - прво о садашњости, бурним догађајима 1848. године, такође и о даљој прошлости, а од 350. стиха почиње опет љубавна прича прекинута у драматичком тренутку, али са приповедачком закључном досетком „Нећу да заглавим” (Безимена: 851). Писана пред крај живота „Безимена”, у ствари само фрагменти, одломци, сведочи о замишљеној, широко планираној целини. Песнички облик - сестина, којом се Бранко служи користећи трохејски осмерац (тзв. sesta rima абабвв) - поред емоционалности - везује Бранково дело за романтизам. Речито вођено приповедање најављује нове могућности, нови правац српској епици - долазак реализма. „Млого хтео, млого започео, / час умрли њега је помео" (Бачки растанак: 28-29).

\footnotetext{
${ }^{5}$ П. Поповић тврди да је то одјек сусрета са П. П. Његошем у Бечу и заносом црногорским владиком (Поповић 1924: XLVII, LXXIX, CXXIV).
} 


\section{ИЗВОРИ}

www.antologijasrpskeknjizevnosti.rs, приступљено 12.08.2016.

\section{ЛИТЕРАТУРА}

Белић 1947: А. Белић, Бранко и Вуков покрет. Кюижевност, бр. 9-10, 283-289. Вуковић 1976: В. Вуковић, Бранко Радичевић, у: Из нашег романтизма. Приштина.

Дамјанов 1997: С. Дамјанов, Бранко и његова поема Пут. Свеске, год. 9, бр. $38,130-131$.

Живковић 1995: Д. Живковић, Поговор, у: Бранко Радичевић, Изабрана дела. Београд.

Жирмунски 1924: Жирмунский В. Байрон и Пушкин. К истории романтической поэмы. Ленинград, с. 44, в: R. Przybylski, Wstęp, y: A. Malczewski, Maria. Wrocław - Kraków 1958, BN I 46, c. CXIV.

Иванић 1999: Д. Иванић, Пјесничко дјело Бранка Радичевића, у: Б. Радичевић, Сабране песме, прир. Д. Иванић, Београд: CК3, VII-LXXII.

Јовићевић 2012: Т. Јовићевић, Песништво Бранка Радичевића и поезија „Успомене на Бранка". Антологијска едиција ДЕСЕТ ВЕКОВА СРПСКЕ КЬИЖЕВНОСТИ, Нови Сад

Клеут 1973: М.Клеут, Бранко Радичевић и народна књижевност. Зборник за славистику св. 5, 31-76.

Остојић 1918: Т. Остојић, Бранко Радичевић и Бајрон, у: Бранко Радичевић 1995, Изабрана дела. Београд.

Поповић 1969: М. Поповић, „Безимена” или без имена. Кюижевна историја, Београд св. 4, 785-820.

Поповић 1919: П. Поповић, Бранко Радичевић и његова „Туга и опомена”. Из Книжевности, св. II, Београд, 83-102.

Поповић 1924: П. Поповић, Бранко Радичевић (увод у: Песме Бранка Радичевића са писмима юеговим и једном списом у прози. У редакцији Б. Миљковића и М. Павловића. Са уводом Павла Поповића. Београд СКЗ.

Радичевић 1999: Б. Радичевић, Сабране песме, прир. Д. Иванић, Београд: Српска књижевна задруга. 
Milica Jakóbiec-Semkowowa

\section{ЭПИЧЕСКАЯ НАРРАЦИЯ В ТВОРЧЕСТВЕ БРАНКА РАДИЧЕВИЧА}

\section{(Резюме)}

Эпические стихи Бранко Радичевича превосходят по объёму его лирические стихи, но во многих исследованиях и монографиях остаются в тени его лирики. Данная работа - попытка исследовать, в какой степени автор поэмы „Расставание со школьными друзьями” овладел искусством эпического жанра, строил ли повествование, опираясь на эпическую традицию предыдущих эпох - классицизма и предромантизма, или же ему ближе были романтические поэмы в стиле Байрона. 